\title{
PENGEMBANGAN INDIKATOR 4C'S YANG SELARAS DENGAN KURIKULUM 2013 PADA MATA PELAJARAN MATEMATIKA SMA/MA KELAS X SEMESTER 1
}

\author{
Sunardi $^{\mathrm{a}}$, Dian Kurniati ${ }^{\mathrm{b}}$, Titik Sugiarti ${ }^{\mathrm{c}}$, Erfan Yudianto $^{\mathrm{d}}$, Rika Nurmaharani ${ }^{\mathrm{e}}$ \\ Program Studi Pendidikan Matematika Universitas Jember (UNEJ) \\ Jln. Kalimantan 37, Jember,. \\ a sunardifkipunej@yahoo.com, ${ }^{\mathrm{b}}$ dian.kurniati@unej.ac.id, ${ }^{\mathrm{c}}$ titiksugiati.fkip@unej.ac.id, \\ derfanyudi@unej.ac.id, ${ }^{\mathrm{d}}$ rikanurmaharani@yahoo.com
}

\begin{abstract}
ABSTRAK
Tujuan penelitian ini adalah untuk menghasilkan indikator 4C's yang selaras dengan kurikulum SMA/MA yang digunakan di Indonesia yaitu kurikulum 2013 pada mata pelajaran matematika SMA kelas $\mathrm{X}$ semester 1 yang terdiri dari 3 bab yaitu: sistem persamaan dan pertidaksamaan linier satu variabel yang memuat nilai mutlak, SPLTV, dan fungsi. Kegiatan penelitian dimulai dari analisis masalah kurikulum di Indonesia dan menganalisis literatur kemampuan 4C's menurut Partnership 21th Century Learning (P21). Kegiatan selanjutnya adalah merancang Indikator 4C,s yang selaras dengan kurikulum 2013 pada mata pelajaran matematika SMA/MA kelas X semester 1. Produk yang dihasilkan yaitu Indikator 4C's yang selaras dengan kurikulum 2013 disajikan dalam vorum diskusi (kolokium). Kemudian produk tersebut direvisi berdasarkan saran dari peserta kolokium. Kegiatan terakhir yaitu membagikan produk yang valid kepada peserta kolokium sebagai panduan penyusunan rencana pembelajaran. Penelitian ini menghasilkan indikator 4C's yang selaras dengan kurikulum di Indonesia yaitu kurikulum 2013.
\end{abstract}

Kata Kunci: Kemampuan 4C's, Kurikulum 2013, Matematika SMA/MA Kelas X Semester 1

\section{ABSTRACT}

The purpose of this research is to produce 4C's indicator which is in line with the curriculum of SMA / MA that is used in Indonesia that is the curriculum of 2013 on the subjects of SMA X semester 1 mathematics consisting of 3 chapters namely: system of equations and linear inequality one variable that contains absolute value, SPLTV, and functions. The research activities started from the analysis of curriculum problems in Indonesia and analyzed the 4C's literature capabilities according to Partnership 21th Century Learning (P21). The next activity is to design Indicator 4C, s which is in line with the 2013 curriculum in the mathematics subjects of SMA / MA class $\mathrm{X}$ semester 1 . The resulting product is the indicator of the $4 \mathrm{C}$ 's consistent with curriculum 2013 are presented in colloquium. Then the product was revised on the advice of the colloquium participants. The last activity is to distribute valid products to colloquium participants as a guide for the preparation of lesson plans. This research produces 4C's indicator that is in line with the curriculum in Indonesia, which is the curriculum of 2013

Keywords: 4C's skill, Curriculum 2013, Mathematics subject in first semester of tenth grade senior high

school 


\section{Pendahuluan}

Pendidikan merupakan hal yang penting dalam kehidupan kita, ini berarti bahwa setiap warga negara indonesia berhak mendapatkan pendidikan dan diharapkan untuk selalu berkembang, sesuai dengan UUD 1945 pasal 31 ayat 1 yang menyatakan bahwa setiap warga negara berhak mendapatkan pendidikan. Pendidikan diyakini banyak kalangan sebagai kunci keberhasilan kompetisi masa depan dan segala sesuatu yang berkaitan dengan kualitas manusia dan pembangunan, senantiasa dikaitkan dengan pendidikan. Sudah menjadi rahasia umum bahwa maju atau tidaknya suatu negara dipengaruhi oleh faktor pendidikan.

Di era globalisasi ini, perkembangan sains dan teknologi meningkat tajam. Standar indikator yang diharapkan pada abad 21 adalah berfokus pada kemampuan berpikir tingkat tinggi karena nantinya pendidikan pada abad 21 akan didominasi oleh pendidikan yang berbasis teknologi. Keterampilan yang dibutuhkan pada abad 21 adalah: (1) Learning and innovation skills; (2) Information, media, and Technology Skills: (3) Life and Career skills (Partnership for 21st Century Learning, 2016). Pendidikan matematika juga dipengaruhi oleh perkembangan ilmu

Pengembangan ... (Sunardi) pengetahuan dan Teknologi itu sendiri. Namun, di Indonesia, kemampuan siswa dalam matematika masih rendah (Kurniati, Annizar, \& ma'ruf, 2017).

Sejak tahun 2000 Indonesia telah bergabung dengan PISA. PISA merupakan sistem ujian yang diinisasi oleh Organisation for Economic Cooperation and Development (OECD), untuk mengevaluasi sistem pendidikan dari 72 negara di seluruh dunia. Sejak tahun 2000 PISA telah melakukan penilaian sebanyak 6 kali penilaian yaitu pada tahun 2000, 2003, 2006, 2009, 2012, dan 2015. Selama penilaian itu, Indonesia cenderung mengalami penurunan pada skor iterasi matematika (OECD, 2016).

Kondisi tersebut juga tidak berbeda jauh dengan hasil studi TIMSS (Trends International Mathematics and Science Study). Dengan melihat hasil skor PISA dan TIMSS, Indonesia masih berada dibawah rerata negara-negara OECD. hal ini merupakan tantangan bagi calon guru dan juga pemerintah untuk meningkatkan kualitas pendidkan, oleh karena itu perlu dilakukan perubahan dalam sistem pendidikan Indonesia.

Pemerintah telah melakukan beberapa kebijakan untuk meningkatkan kualitas pendidikan di Indonesia salah satunya yaitu memberlakukan kurikulum 
2013 yang telah diterapkan beberapa sekolah di Indonesia sejak tahun 2014. Kurikulum 2013 merupakan salah satu upaya pemerintah untuk mencapai keunggulan masyarakat bangsa dalam pengusaan ilmu dan teknologi seperti yang digariskan dalam haluan negara. Dengan demikian kurikulum 2013 dapat menyelesaikan berbagai permasalahan yang sedang dihadapi oleh dunia pendidikan dewasa ini, terutama dalam memasuki era globalisai yang penuh dengan berbagai macam tantangan (Mulyasa, 2013).

Era abad digital atau era masyarakat ekonomi global yang ditandai antara lain: informasi tersedia dimana saja dan dapat diakses kapan saja; komputasi merupakan prinsip tumpuan pemrosesan informasi/data lebih cepat; otomasi merupakan prinsip pelaksanaan pekerjaan rutin yang lebih cepat; dan komunikasi merupakan prinsip penyampaian informasi yang dapat dilaksanakan dari mana saja, kemana saja, dan kapan saja. Keterampilan belajar yang diperlukan siswa agar bisa sukses dalam bekerja dan berkarir di era masyarakat ekonomi global adalah Critical Thinking and Problem Solving, Communication, Collaboration, and Creativity and Innovation (Sunardi, 2017).
Hal tersebut sesuai dengan Indikator kemampuan inovasi dan pembelajaran matematika menurut P21 yang biasa disebut 4C's yaitu critical thinking (berfikir kritis), communication (komunikasi), collaboration (kolaborasi), dan creativity (kreatif). Beberapa negara di dunia telah menggunakan 4C's.Hidup dan bekerja di abad 21, menurut prediksi kementrian (Partnership) akan membutuhkan pengetahuan, keterampilan, hasil, standar, dan sistem pendukung yang belum pernah diberikan oleh sekolah (Bellanca, 2010). Oleh karena itu, perlu dilakukan penyelarasan indikator 4C's terhadap kurikulum Indonesia yaitu kurikulum 2013 khususnya pada mata pelajaran Matematika.

Menurut Dewey (dalam Fisher, 2009: 2-5), berpikir kritis adalah proses berpikir yang teliti dan tidak terburu-buru dalam mengambil sebuah keputusan atau kesimpulan atau biasa disebut dengan berfikir aktif, jadi tidak hanya menerima begitu saja informasi dan gagasangagasan yang didapat dari orang lain atau yang disebut dengan proses berfikir pasif. Berpikir kritis matematis merupakan dasar proses untuk menganalisis argumen dan memunculkan gagasan terhadap tiap makna untuk mengembangkan pola pikir secara logis (Tanti \& Hasratuddin, 2015). 
Menurut Ennis dalam Costa

(1985: 16) terdapat 5 kelompok keterampilan berpikir kritis yaitu, (1)

Memberikan penjelasan sederhana, (2)

Membangun keterampilan dasar, (3)

Menyimpulkan, (4) Memberikan

penjelasan lanjut, (5) Mengatur strategi dan taktik. Keterampilan berpikir kritis terdiri dari, menggunakan penalaran induktif (umum-khusus) atau penalaran deduktif (khusus-umum), menganalisis keterkaitan masing-masing bagian dari keseluruhan untuk menghasilkan sistem yang kompleks, menganalisis dan mengevaluasi fakta-fakta, menarik kesimpulan berdasarkan hasil analisis dan menyelesaikan masalah yang tidak biasa/umum (Partnership for 21st Century Learning, 2016).

Pehkonen (dalam Siswono, 2009) mendefinisikan berpikir kreatif sebagai kombinasi antara berpikir logis dan berpikir divergen yang didasarkan pada intuisi tapi masih dalam kesadaran. Ketika seseorang menerapkan berpikir kreatif dalam suatu praktek pemecahan masalah, pemikiran divergen menghasilkan banyak ide yang berguna dalam menyelesaikan masalah. Proses berpikir kreatif didasarkan pada tiga proposisi kritis yaitu: Pertama, pemecahan masalah kreatif, seperti bentuk pemecahan masalah lainnya,harus

Pengembangan ... (Sunardi) didasarkan pada pengetahuan dan informasi mengingat intinya pengetahuan memberikan dasar untuk menafsirkan informasi. Kedua, seseorang tidak dapat menghasilkan gagasan baru semata-mata atas dasar pengetahuan yang ada. Tetapi sebaliknya, pengetahuan ini harus direkombinasi dan direorganisasi untuk menghasilkan pengetahuan baru yang memungkinkan untuk menghasilkan gagasan baru. Ketiga, ide harus dievaluasi dan dibentuk ke dalam rencana yang layak untuk mengarahkan proyek proyek kreatif (Mumford D., Kelsey E. \& Medeiros, 2012). Menurut P21, keterampilan kreatif terdiri dari menciptakan ide baru, memperluas ide/konsep dasar untuk meningkatkan dan memaksimalkan upaya kreatif dan mengaplikasikan ide kreatif sebagai kontribusi nyata dalam kehidupan.

Menurut Suryani (2010), pembelajaran kolaborasi menekankan adanya prinsip-prinsip kerja. Prinsipprinsip penting yang perlu diperhatikan dalam pembelajaran kolaborasi tersebut adalah sebagai berikut: Setiap anggota melakukan kerja sama untuk mencapai tujuan bersama dan saling ketergantungan, Individu-individu bertanggung jawab atas dasar belajar dan perilaku masing-masing, Kelas atau kelompok didorong ke arah terjadinya 
pelaksanaan suatu aktivitas kerja kelompok yang kohesif. Sedangkan menurut P21, pembelajaran kolaorasi yaitu menunjukkan kemampuan untuk bekerja secara efektif dengan kelompok yang berbeda, dan menerima pembagian tanggung jawab dan memberi kontribusi dalam menyelesaikan tugas kelompok.

Aspek-aspek dalam kemampuan komunikasi matematis yang telah dikaji oleh MCTM (2000) terdiri dari 3 bagian, yaitu (1) kemampuan menyatakan gagasan matematis secara lisan, tulisan, serta menggambarkan secara visual, (2) kemampuan menginterpretasikan dan mengevaluasi gagasan-gagasan matematika secara lisan maupun tertulis, (3) kemampuan menggunakan istilahistilah, simbol-simbol, dan strukturstruktur untuk memodelkan situasi atau permasalahan matematika. Sedangkan indikator komuniksai menurut P21 yaitu: Mengungkapkan pikiran atau ide melalui lisan, tulisan atau nonverbal, menggunakan komunikasi untuk berbagai tujuan (misalnya menginformasikan, mengintruksikan, memotivasi atau mengajak), menggunakan berbagai media atau teknologi dalam pembelajaran.

Tujuan penelitian ini adalah untuk menghasilkan indikator 4C's yang selaras dengan kurikulum SMA/MA yang digunakan di Indonesia yaitu kurikulum
2013 pada mata pelajaran matematika SMA kelas X semester 1

\section{Metode Penelitian}

Jenis penelitian ini adalah penelitian pengembangan. Tujuan dari penelitian ini adalah untuk menghasilkan indikator 4C's yang selaras dengan kurikulum Indonesia yaitu kurikulum 2013 pada mata pelajaran matematika SMA/MA kelas $X$ Semester 1 yang terdiri dari 3 bab yaitu: Sistem persamaan dan pertidaksamaan linier satu variabel yang memuat nilai mutlak, SPLTV, dan fungsi. Kegiatan penelitian dimulai dari analisis masalah kurikulum di Indonesia dan menganalisis literatur kemampuan 4C's menurut Partnership 21th Century Learning (P21). Kegiatan selanjutnya adalah merancang Indikator 4C's yang selaras dengan kurikulum 2013 pada mata pelajaran matematika SMA/MA kelas X semester 1 yaitu . Produk yang dihasilkan yaitu Indikator 4C's yang selaras dengan kurikulum 2013 disajikan dalam vorum diskusi (Kolokium) yang dihadiri oleh tiga dosen pendidikan matematika Universitas Jember, dan dua guru matematika MAN 1 Jember. Kemudian produk tersebut direvisi berdasarkan saran dari peserta seminar. Kegiatan terakhir yaitu membagikan produk yang valid kepada peserta seminar sebagai panduan penyusunan 
rencana pembelajaran. Penelitian ini menghasilkan indikator 4C's yang selaras dengan kurikulum di Indonesia yaitu kurikulum 2013.

\section{Hasil dan Pembahasan}

Penelitian sebelumnya tentang berpikir kritis, kreatif, komunikasi dan kolaborasi sudah banyak dilakukan. Namun, penelitian yang sejenis dengan penelitian ini belum ada. Berbagai penelitian yang dilakukan mengutip beberapa pendapat ahli tentang berpikir kritis, kreatif, komunikasi dan kolaborasi. Setelah dibandingkan antara keterampilan yang dipakai oleh peneliti lain dengan keterampilan dari P21 dengan kurikulum Indonesia yaitu Kurikulum 2013, keduanya memiliki kesamaan yang signifikan, hanya terdapat keterampilan yang khas yang dimiliki oleh kerampilan P21.

Tabel 1. Perbandingan keterampilan berpikir kritis pada penelitian ini dan menurut ahli

\begin{tabular}{ccc}
\hline Keterampilan & $\begin{array}{c}\text { Keterampilan berpikir krritis pada } \\
\text { penelitian ini }\end{array}$ & $\begin{array}{c}\text { Keterampilan berpikir kritis } \\
\text { menurut Ennis }\end{array}$ \\
\hline Berpikir Kritis & $\begin{array}{c}\text { 1. Menggunakan penalaran induktif } \\
\text { atau penalaran deduktif }\end{array}$ & $\begin{array}{c}\text { 1. Memberikan penjelasan } \\
\text { sederhana }\end{array}$ \\
& $\begin{array}{c}\text { 2. Menganalisis keterkaitan masing- } \\
\text { masing bagian dari keseluruhan }\end{array}$ & 2. Membangun keterampilan \\
& untuk menghasilkan sistem yang & 3. Menyimpulkan \\
& kompleks & 4. Memberikan penjelasan \\
3. Menganalisis dan mengevaluasi & lanjut \\
fakta-fakta. & 5. Mengatur strategi dan taktik \\
4. Menarik kesimpulan berdasarkan & \\
hasil analisis & \\
5. Menyelesaikan masalah yang tidak & \\
biasa/umum dengan cara & \\
konvensional maupun inovatif & \\
\hline
\end{tabular}

Berdasarkan Tabel 1. Terdapat kesamaan disetiap indikator antara keterampilan 4C's dengan keterampilan berpikir kritis menurut Ennis. Ditemukan perbedaan antara keduanya, yaitu Pengembangan ... (Sunardi) terdapat indikator menyelesaikan masalah yang tidak biasa/umum pada keterampilan 4C's. Pada keterampilan menurut Ennis, hanya menekankan pada proses berpikirnya, tidak terdapat 
penyelesaian masalah. Pada penelitian ini, keterampilan 4C's berupa berpikir kritis terhadap kurikulum di Indonesia yaitu menentukan daerah hasil pertidaksamaan linier satu variabel dengan menggunakan program linier.

Tabel 2. Perbandingan kreatif pada penelitian ini dan menurut ahli

\begin{tabular}{|c|c|c|}
\hline Keterampilan & $\begin{array}{l}\text { Keterampilan kreatif } \\
\text { pada penelitian ini }\end{array}$ & Keterampilan kreatif menurut Mumford \\
\hline Kreatif & $\begin{array}{l}\text { 1. Menciptakan ide baru } \\
\text { 2. Memperluas ide/konsep } \\
\text { dasar untuk } \\
\text { meningkatkan dan } \\
\text { memaksimalkan upaya } \\
\text { kreatif } \\
\text { 3. Mengaplikasikan ide } \\
\text { kreatif sebagai } \\
\text { kontribusi nyata dalam } \\
\text { kehidupan }\end{array}$ & $\begin{array}{l}\text { 1. Pemecahan masalah kreatif harus } \\
\text { didasarkan pada pengetahuan dan } \\
\text { informasi mengingat intinya pengetahuan } \\
\text { memberikan dasar untuk menafsirkan } \\
\text { informasi. } \\
\text { 2. Mengkombinasi dan mereorganisasi untuk } \\
\text { menghasilkan pengetahuan baru yang } \\
\text { memungkinkan untuk menghasilkan } \\
\text { gagasan baru. } \\
\text { 3. Ide harus dievaluasi dan dibentuk ke } \\
\text { dalam rencana yang layak untuk } \\
\text { mengarahkan proyek proyek kreatif }\end{array}$ \\
\hline
\end{tabular}

Berdasarkan Tabel 2. sebagai kontribusi nyata dalam Keterampilan kreatif 4C's dan kehidupan berupa proyek-proyek kreatif. keterampilan kreatif dari (Mumford Dalam penelitian ini, keterampilan et.al.'s, 1991) memiliki kesamaan yang tersebut telah diselaraskan dengan sangat relevan antara keduanya yaitu kurikulum 2013 yaitu menciptakan ide menciptakan ide baru yang didasari oleh kreatif dalam menemukan masalah pengetahuan yang kemudian sehari-hari tentang konsep fungsi.

mengaplikasikan ide kreatif tersebut 
Tabel 3. Perbandingan komunikasi pada penelitian dan menurut ahli

\begin{tabular}{|c|c|c|}
\hline Keterampilan & $\begin{array}{c}\text { Keterampilan komunikasi } \\
\text { pada penelitian ini }\end{array}$ & $\begin{array}{c}\text { Keterampilan komunikasi } \\
\text { menurut NCTM }\end{array}$ \\
\hline Komt & $\begin{array}{l}\text { 1. Mengungkapkan pikiran atau } \\
\text { ide melalui lisan, tulisan atau } \\
\text { nonverbal } \\
\text { 2. Menggunakan komunikasi } \\
\text { untuk berbagai tujuan } \\
\text { (misalnya menginformasikan, } \\
\text { mengintruksikan, memotivasi } \\
\text { atau mengajak) } \\
\text { 3. Menggunakan } \\
\text { media atau teknologi dalam } \\
\text { pembelajaran }\end{array}$ & $\begin{array}{l}\text { 1. Kemampuan menyatakan gagasan } \\
\text { matematis secara lisan, tulisan, } \\
\text { serta menggambarkan secara } \\
\text { visual. } \\
\text { 2. Kemampuan menginterpretasikan } \\
\text { dan mengevaluasi gagasan- } \\
\text { gagasan matematika secara lisan } \\
\text { maupun tertulis. } \\
\text { 3. Kemampuan menggunakan } \\
\text { istilah-istilah, simbol-simbol, dan } \\
\text { struktur-struktur untuk } \\
\text { memodelkan situasi atau } \\
\text { permasalahan matematika. }\end{array}$ \\
\hline
\end{tabular}

Berdasarkan Tabel 3. diatas, dapat disimpulkan bahwa keterampilan 4C's telah mewakili seluruh keterampilan komuniksi menurut (NCTM, 2000). Namun terdapat perbedaan antara keduanya yaitu pada keterampilan komunikasi menurut (NCTM, 2000) tidak terdapat indikator yang menjelaskan bahwa dalam keterampilan komunikasi menggunakan berbagai media atau teknologi dalam pembelajaran. Hal ini sangat penting dalam menghadapi kehidupan pada abad 21 ini. Pada penelitian ini telah diselaraskan indikator 4C's dengan kurikulum 2013, salah satu contoh indikator yang menggunakan media dan teknologi adalah menentukan hasil operasi matematika pada fungsi. 
Tabel 4. Perbandingan kolaborasi pada penelitian ini dan menurut ahli

\begin{tabular}{|c|c|c|}
\hline Keterampilan & $\begin{array}{l}\text { Keterampilan kolaborasi } \\
\text { pada penelitian ini }\end{array}$ & $\begin{array}{c}\text { Keterampilan kolaborasi menurut } \\
\text { Suryani }\end{array}$ \\
\hline \multirow[t]{3}{*}{ Kolaborasi } & $\begin{array}{l}\text { 1. Menunjukkan kemampuan } \\
\text { untuk bekerja secara efektif } \\
\text { dalam kelompok }\end{array}$ & $\begin{array}{l}\text { 1. Setiap anggota melakukan } \\
\text { kerja sama untuk mencapai tujuan } \\
\text { bersama dan saling ketergantungan }\end{array}$ \\
\hline & $\begin{array}{lr}\text { 2. Menerima } & \text { pembagian } \\
\text { tanggungjawab dan memberi } \\
\text { kontribusi } & \text { dalam }\end{array}$ & $\begin{array}{l}\text { 2. Individu-individu bertanggung } \\
\text { jawab atas dasar belajar dan perilaku } \\
\text { masing-masing }\end{array}$ \\
\hline & $\begin{array}{l}\text { menyelesaikan tugas } \\
\text { kelompok } \\
\text { 3. Memberikan masukan dan } \\
\text { menunjukkan rasa saling } \\
\text { menghargai sesama teman }\end{array}$ & $\begin{array}{l}\text { 3. Kelas atau kelompok didorong } \\
\text { ke arah terjadinya pelaksanaan suatu } \\
\text { aktivitas kerja kelompok yang } \\
\text { kohesif. }\end{array}$ \\
\hline
\end{tabular}

Berdasarkan Tabel 4. diatas, terlihat bahwa keterampilan kolaborasi pada penelitian ini dan keterampilan komunikasi munurut (Suryani, 2010) memiliki kesamaan yang relevan. Kemampuan kolaborasi, tidak hanya bekerja sama di satu kelompok, namun juga harus menciptakan kerja kelompok yang kohesif di dalam kelas dengan memberikan masukan dan saling menghargai pendapat antar kelompok. Setelah dilakukan penyelarasan terhadap kurikulum 2013, terdapat indikator yang memberikan masukan dan saling menghargai antar kelompok yaitu menanggapi presentasi hasil diskusi kelompok lain mengenai konsep nilai mutlak.

Setelah pengembangan dilakukan, hasil dari pengembangan ini divalidasi oleh 5 validator. Saran revisi dari validator terhadap indikator 4C's yang telah dikembangkan dapat dilihat pada Tabel

5. berikut. 
Tabel 5. Saran Revisi dari Validator terhadap Indikator 4C's

\begin{tabular}{|c|c|c|}
\hline No. & Validator & Saran \\
\hline 1 & Validator 1 & $\begin{array}{l}\checkmark \text { Perlu ada perbaikan pada tata tulis } \\
\checkmark \text { Perlu ada perbaikan tata bahasa yang digunakan pada } \\
\text { bagian indikator. } \\
\checkmark \text { Perlu ditambahkan kegiatan pembelajaran pada kolom } \\
\text { hasil pengembangan indikator agar lebih memperjelas } \\
\text { maksud dari indikator }\end{array}$ \\
\hline 2 & Validator 2 & $\begin{array}{l}\checkmark \text { Perlu adanya penjelasan pada bagian-bagian indikator 4C's } \\
\text { sehingga tidak rancu } \\
\checkmark \text { Perlu adanya perbaikan pada tata tulis } \\
\checkmark \text { Pada skala penskoran, disarankan pada semua kriteria } \\
\quad \text { penilaian menggunakan skala } 1-4 \text {. }\end{array}$ \\
\hline 3 & Validator 3 & $\begin{array}{l}\checkmark \text { Perlu adanya perbaikan pada tata tulis } \\
\checkmark \text { Pada lembar validasi, pada kriteria penilaian indiator } \\
\text { sesuai dengan kemampuan 4C's diperjelas. Disebutkan } \\
\text { kemampuannya. } \\
\checkmark \text { Pada metode penelitian disarankan untuk menggunakan } \\
\text { analisis data menurut Hobri, yang sebelumya } \\
\text { menggunakan Arikunto. }\end{array}$ \\
\hline 4 & Validator 4 & $\begin{array}{l}\checkmark \text { Perlu ada perbaikan tata bahasa yang digunakan pada } \\
\quad \text { bagian indikator. }\end{array}$ \\
\hline 5 & Validator 5 & $\begin{array}{l}\checkmark \text { Perlu ada perbaikan tata bahasa yang digunakan pada } \\
\text { bagian indikator. }\end{array}$ \\
\hline
\end{tabular}

Berdasarkan seluruh kegiatan yang telah dilakukan pada proses pengembangan, seluruh data dan hasil validasi direkap dan dianalisis untuk mengetahui apakah perangkat yang dihasilkan telah memenuhi kriteria kevalidan atau tidak. Berdasarkan hasil analisis yang telah dilakukan, diperoleh koefisien validitas sebesar 3,86. Berdasarkan hasil koefisien validitas tersebut, maka produk yang dihasilkan yaitu indikator 4C's yang diselaraskan dengan kurikulum 2013 mempunyai kategori interpretasi valid. Berikut adalah contoh hasil pengembangan indikator 4C's yang diselaraskan dengan kurikulum 2013 pada mata pelajaran matematika SMA/MA kelas X semester 1. 
Tabel 6. Contoh Hasil Pengembangan Indikator 4C's yang Selaras dengan Kurikulum 2013

\begin{tabular}{|c|c|c|}
\hline $\begin{array}{l}\text { Kemamp } \\
\text { uan 4C's }\end{array}$ & Keterampilan P21 & Indikator \\
\hline \multirow[t]{4}{*}{$\begin{array}{l}\text { Critical } \\
\text { Thinking }\end{array}$} & Menyelesaikan masalah & $\begin{array}{l}\text { Memecahkan masalah kontekstual yang } \\
\text { terkait dengan persamaan nilai mutlak }\end{array}$ \\
\hline & $\begin{array}{c}\text { Membuat pertimbangan dan } \\
\text { keputusan }\end{array}$ & $\begin{array}{l}\text { Menganalisis perbedaan antara interval } \\
\text { terbuka dengan interval tertutup }\end{array}$ \\
\hline & Menyelesaikan masalah & $\begin{array}{l}\text { Menentukan daerah hasil PtLSV dengan } \\
\text { menggunakan profram linier }\end{array}$ \\
\hline & Menyelesaikan masalah & $\begin{array}{l}\text { Menyelesaikan masalah PtLSV yang } \\
\text { memuat nilai mutlak }\end{array}$ \\
\hline \multirow[t]{2}{*}{ Creative } & Bekerja kreatif & $\begin{array}{l}\text { Mengembangkan ide-ide baru dalam } \\
\text { menemukan hubungan antara dua } \\
\text { himpunan penyelesaian pertidaksamaan }\end{array}$ \\
\hline & $\begin{array}{l}\text { Implementasi berpikir kreatif } \\
\text { dsn bekerja kreatif }\end{array}$ & $\begin{array}{l}\text { Memunculkan ide-ide kreatif untuk } \\
\text { memberi contoh penerapan PtLSV yang } \\
\text { memuat nilai mutlak dalam kehidupan } \\
\text { sehari-hari }\end{array}$ \\
\hline \multirow[t]{2}{*}{$\begin{array}{l}\text { Collabora } \\
\text { tion }\end{array}$} & $\begin{array}{l}\text { Menerima pembagian tanggung } \\
\text { jawab untuk kerja kolaborasi }\end{array}$ & $\begin{array}{l}\text { Menyampaikan ide atau pendapat dalam } \\
\text { menemukan sifat-sifat pertidaksamaan } \\
\text { linier kepada teman sekelompok }\end{array}$ \\
\hline & $\begin{array}{l}\text { Bekerja secara efektif dengan } \\
\text { kelompok yang berbeda }\end{array}$ & $\begin{array}{l}\text { Menanggapi presentasi hasil diskusi } \\
\text { kelompok lain mengenai sifat-sifat dasar } \\
\text { pertidaksamaan linier }\end{array}$ \\
\hline \multirow[t]{2}{*}{$\begin{array}{l}\text { Communi } \\
\text { cation }\end{array}$} & $\begin{array}{l}\text { Mengartikulasikan pikiran dan } \\
\text { ide secara efektif }\end{array}$ & $\begin{array}{l}\text { Menggambar grafik persamaan nilai } \\
\text { mutlak dengan menggunakan software } \\
\text { graphmatica }\end{array}$ \\
\hline & $\begin{array}{l}\text { Memanfaatkan media dan } \\
\text { teknologi yang ada }\end{array}$ & $\begin{array}{l}\text { Mempresentasikan hasil diskusi kelompok } \\
\text { mengenai sifat-sifat dasar pertidaksamaan } \\
\text { linier di depan kelas }\end{array}$ \\
\hline
\end{tabular}

Penelitian pengembangan indikator 4C's yang selaras dengan kurikulum 2013 ini belum pernah dilakukan penelitian yang sejenis sebelumya. Telah banyak dilakukan penelitian sebelumnya mengenai keterampilan berpikir kritis, kreatif, kolaborasi, dan komunikasi. Penelitian tersebut mengutip teori-teori dari para ahli mengenai kemampuan berpikir kritis, kreatif, kolaborasi, dan komunikasi. Pada penelitian ini, menggunakan keterampilan P21 yang kemudian di reduce sesuai dengan kebutuhan penyelaraan terhadap kurikulum di Indonesia yaitu kurikuum 2013. Sesuai 
dengan Tabel 1, 2, 3, dan 4 terdapat kesamaan antara keterampilan menurut para ahli dan keterampilan menurut P21. Hanya terdapat sedikit perbedaan pada keterampilan menurut P21 yaitu memiliki keterampilan yang baru untuk menghadapi abad 21 ini.

Dari 10 kompetensi dasar terdapat 27 indikator dari kemampuan Critical Thinking, 19 indikator kemampuan Creative, 20 indikator kemampuan Colaboration, dan 19 indikator kemampuan Communication. Dari hasil tersebut kemampuan Collaboration sangat sulit dikembangkan karena tersekesan monoton hanya terfokus pada kegiatan sosial antar siswa. Kemampuan Creative menurut P21 siswa dituntut mengimplementasikan ide baru dalam kehidupan dunia nyata, tentunya tidak mudah untuk mengembangkan indikator yang memenuhi kemampuan Creative ini melihat dari siswa yang harus memiliki kemampuan berfikir tingkat tinggi. Tidak hanya siswa, melainkan guru juga harus kreatif mengembangkan indikator sehingga dapat memunculkan kekreatifan siswa.

Hasil indikator yang selaras dengan kurikulum Indonesia yaitu kurikulum 2013 pada mata pelajaran matematika SMA/MA kelas X Semester 1 ini telah dilakukan revisi sesuai saran

Pengembangan ... (Sunardi) dari peserta kolokium. Peserta kolokium merespon positif terhadap hasil pengembangan ini karena masih belum ada indikator yang diselaraskan dengan indikator 4C's dan juga membantu peserta kolokium dalam pembuatan rencana pembelajaran.

\section{Kesimpulan}

Berdasarkan hasil penelitian dan pembahasan dari penyelarasan keterampilan 4 C's terhadap kurikulum di Indonesia, dapat disimpulkan bahwa:

1. Indikator yang selaras dengan kurikulum 2013 pada mata pelajaran matematika SMA/MA kelas $\mathrm{X}$ semester 1 telah layak digunakan dan disebarluaskan setelah dilakukan beberapa revisi sesuai dengan saran dari peserta kolokium.

2. Terdapat beberapa indikator 4C's yang unik dan memiliki kelebihan tersendiri dibanding dengan kurikulum 2013 yaitu: pada keterampilan Critical Thinking adalah menentukan daerah hasil pertidaksamaan linier satu variabel dengan menggunakan program linier. Pada keterampilan Creative, indikator yang dihasilkan adalah memunculkan ide-ide kreatif untuk memberi contoh penerapan PtLSV yang memuat nilai mutlak dalam kehidupan sehari-hari. Indikator 
yang dihasilkan pada keterampilan

Collaboration adalah memberi tanggapan terhadap hasil presentasi kelompok lain. Pada keterampilan Communication, indikator yang dihasilkan adalah mempresentasikan hasil diskusi kelompok di depan kelas.

\section{Ucapan Terimakasih}

Penulis mengucapkan terima kasih kepada Allah SWT berkat ridhonya dapat menyelesaikan artikel ini. Kedua orang tua yang selalu memberikan dukungan dan semangat, serta kepada dosen pembimbing, dosen penguji, dan peserta kolokiumr yang telah membimbing dalam menyelesaikan penelitian ini.

\section{Pustaka}

Bellanca. James. 2010. Enriched Learning Project. Bloomington: Solution Tree Press. Terjemahan oleh Ririn Sjafriani. 2012. Proyek Pembelaaran yang Diperkaya. Jakarta: PT Indeks Permata Puti Media.

Chao Yu, K., Yi Lin, K., \& Fen Chang, S. (2016). Development and validation of a mechanical critical thinking scale for high school student. EURASIA Journal of Mathematics science and Technology education, 13611376.

Fisher, Alec. 2008. Critical Thinking: An Introduction. Jakarta: Penerbit Erlangga.
Jumaisyaroh, T., dan Hasratuddin. (2015). Peningkatan Kemampuan Berpikir Kritis Matematis dan Kemandirian Belajar Siswa SMP Melalui Pembelajaran Berbasis Masalah. AdMathEdu. Vol. 5 No.1. Kemendikbud. (2016). Silabus Mata Pelajaran Sekolah Menengah Pertama/Madrasah Tsanawiyah (SMP/MTs). Indonesia:

Kemendikbud.

D. Kurniati and A. M. Annizar. (2017). "The Analysis of Students' Cognitive Problem Solving Skill in Solving PISA Standard-Based Test Item," Advanced Science Letters, vol. 23, no. 2, pp. 776-780.

Michael D. Mumford, Kelsey E. Medeiros, Paul J. Partlow. (2012). Creative Thinking: Processes, Strategies, and Knowlegge. The Journal of Creative Behavior. Vol. $46,30-47$.

Mulyasa. 2013. Pengembangan dan Implementasi Kurikulum 2013. Bandung: PT Remaja Rosdakarya.

NCTM. (2000). Principles and Standards for School Mathematics. Virginia: NCTM.

OECD. (2004). First Result from PISA 2003. Paris: OECD Publishing.

OECD. (2004). First Result From PISA 2003. Paris: Organisation of Economics and Co-operation Development.

OECD. (2007). PISA 2006 Key Result. Paris: OECD Publishing.

OECD. (2007). PISA 2006 Science Competencies for Tomorrow's World. Paris: Organisation for Economics Co-operation and Development.

OECD. (2013). PISA 2012 Result in Focus. Paris: OECD Publishing. 
OECD. (2016). Result from PISA 2015.

Paris: OECD Publishing.

OECD. (2017). The Nature of Problem Solving Using Research to Inspire 21st Century Learning. Paris: OECD Publishing.

Partnership for 21st Century Learning. (2016, Agustus 6). P21. Retrieved from P21 Web site: http://www.p21.org.

Sunardi. (2016). Strategi Penguatan Pengembangan 4C's dalam Pembelajaran Matematika. Prosiding Seminar Nasional Matematika (pp. 8-19). Malang: CV. Bintang Sejahtera.

Suryani, Nunuk. 2003. Implementasi Model Pembelajaran Kolaboratif untuk Meningkatkan

Keterampilan Sosial Siswa. 